\title{
Detection of a New Mutation in the $\beta$-Myosin Heavy Chain Gene in an Individual with Hypertrophic Cardiomyopathy
}

\author{
Ali J. Marian, Qun-Tao Yu, Adolph Mares, Jr., Rita Hill, Robert Roberts, and M. Benjamin Perryman* \\ Section of Cardiology, Department of Medicine, Baylor College of Medicine, Houston, Texas 77030; and *Section of Cardiology, \\ Department of Medicine, University of Colorado, Denver, Colorado 80262
}

\begin{abstract}
Familial hypertrophic cardiomyopathy (FHCM) is an autosomal dominant disease affecting primarily the myocardium. The gene responsible for FHCM has been localized to chromosome 14 in some families and several mutations have been described in the $\beta$-myosin heavy chain ( $\beta$ MHC), a candidate gene for the disease. We recently identified a family with $\mathrm{HCM}$ in whom we did not detect any of the known mutations in the $\beta M H C$ gene (the $\alpha / \beta \mathrm{MHC}$ hybrid gene and the missense mutation in exons 13 and 9). However, we did observe a novel 9.5-kb BamHI restriction fragment length polymorphism detected by a $\beta \mathrm{MHC}$ probe on Southern blots of DNA from the proband of this family. Similarly, a novel 3.8-kb TaqI polymorphism and a novel 4.3-kb HindIII polymorphism were detected on Southern blots of DNA from the same proband. Polymerase chain reaction (PCR) was used to amplify the segment of the $\beta M H C$ that was detected by pSC14 probe. PCR amplification of the distal 3 -end of the $\beta M H C$ gene yielded an additional product in the DNA template from the proband which was subsequently cloned and sequenced. The sequence analysis showed a 2.4-kb nucleotide deletion involving one allele of the $\beta \mathrm{MHC}$ gene. The deletion includes part of the intron 39, exon 40 including the 3 -untranslated region and the polyadenylation signal, and part of the $\beta-\alpha \mathrm{MHC}$ intergenic region. This deletion was inherited in Mendelian fashion in an additional three members of this small family of which only the proband has developed clinically diagnosed HCM at a very late onset (age $59 \mathrm{yr}$ ), the other three family members are younger and have not developed the disease at the ages of 10, 32, and $33 \mathrm{yr}$. (J. Clin. Invest. 1992. 90:2156-2165.) Key words: deletion - polymerase chain reaction • restriction fragment length polymorphism • Southern blot
\end{abstract}

\section{Introduction}

Familial hypertrophic cardiomyopathy $(\mathrm{FHCM})^{1}$ is an autosomal dominant disease that affects primarily the myocardium, resulting in inappropriate growth and hypertrophy. While it is a cause of heart failure later in life, in the young it is a common

Address reprint requests to Dr. Roberts, Section of Cardiology, 6535 Fannin, F905, Houston, TX 77030.

Received for publication 20 December 1991 and in revised form 1 July 1992.

1. Abbreviations used in this paper: FHCM, familial hypertrophic BMHC, $\beta$-myosin heavy chain; RFLP restriction fragment length polymorphism; RT PCR, reverse transcription polymerase chain reaction.

J. Clin. Invest.

(C) The American Society for Clinical Investigation, Inc.

$0021-9738 / 92 / 12 / 2156 / 10 \quad \$ 2.00$

Volume 90, December 1992, 2156-2165 cause of sudden death and is the most common cause in young athletes (1). The pathological, hemodynamic, and clinical manifestations of HCM have been studied extensively for decades (2). The myriad of manifestations reflective of diverse pathophysiology include asymmetrical and concentric hypertrophy, decreased myocardial compliance, and outflow tract obstruction. HCM represents a paradigm of cardiac pathophysiology and elucidation of its molecular basis should provide information fundamental to our understanding of the biology and pathology of the myocardium. The gene responsible for FHCM has been localized in some families to chromosome 14 $(3-6)$, and the $\beta$-myosin heavy chain $(\beta \mathrm{MHC})$ gene has been identified as the candidate gene for this disease (3-5). Three mutations in $\beta$ MHC gene in two families with FHCM have been described. The first, an $\alpha / \beta$ cardiac myosin hybrid gene described by Tanigawa et al. (7) occurred in all affected members of a single family with FHCM as a result of a crossover event between $\alpha$ - and $\beta$ MHC genes occurred on exon 27. A missense mutation in exon 13 of $\beta \mathrm{MHC}$ gene has been found in all affected members of another family with FHCM (8). Similarly, another missense mutation in exon 9 of the $\beta \mathrm{MHC}$ gene has been described in a family with FHCM (9). We have examined DNA from the probands of 59 families with FHCM and have detected the exon 13 missense mutation in a single family, but did not detect the $\alpha / \beta$ hybrid gene in any family. However, during this study, we identified a unique restriction fragment length polymorphism (RFLP) on Southern blots of the DNA of a small family in whom the proband has HCM and showed that it was inherited in a Mendelian manner in two subsequent generations. Using polymerase chain reaction (PCR) to amplify DNA from the proband, we have determined that the RFLP represents a deletion in the $\beta \mathrm{MHC}$ gene. The deletion is $2.4 \mathrm{~kb}$ long and extends from intron 39 of the $\beta \mathrm{MHC}$ gene into the intergenic region between the $\beta$ - and $\alpha \mathrm{MHC}$ genes. Included within the deletion is exon 40 which contains coding sequence for the carboxy-terminal five amino acids, the stop codon, and entire $3^{\prime}$-untranslated sequence.

\section{Methods}

Patient studies. Patient evaluation was done as previously reported (5). Briefly, the proband and all members of family 151 (pedigree depicted on the top portion of Fig. 2) were given detailed cardiovascular examinations and two-dimensional echocardiography. The echocardiographic criteria for the diagnosis of HCM was defined as the presence of septal or ventricular hypertrophy with a wall thickness of $13 \mathrm{~mm}$ or more in the absence of other potential causes such as hypertension.

Southern blot analysis. Following informed consent blood was collected from individuals and lymphoblastoid cell lines established by Epstein-Barr virus transformation (10). DNA was prepared from the cell lines using a nucleic acid extractor (Applied Biosystems, Inc., Foster City, CA). DNA was digested with a threefold excess of appropriate restriction endonucleases following the supplier's recommendation. DNA fragments were separated by agarose gel electrophoresis and 
Table I. Primers Used in the Representative PCR Reactions and the Corresponding Amplified Segments of the $\beta M H C$ Gene

\begin{tabular}{|c|c|c|c|c|}
\hline $\begin{array}{l}\text { PCR } \\
\text { reaction }\end{array}$ & & Primer sequence & $\begin{array}{l}\text { Corresponding } \\
\text { nucleotide location } \\
\text { in the } \beta \mathrm{MHC} \text { gene }\end{array}$ & $\begin{array}{l}\text { Length of the } \\
\text { amplified } \\
\text { product }\end{array}$ \\
\hline & & & & $b p$ \\
\hline \multirow[t]{2}{*}{ A } & Sense & 5'-TGAAGCTTACCCAGGAGAGCATCATGG-3' & $15839-19015$ & 3,177 \\
\hline & Antisense & 5'-AAGAATTCTTGGAGAACTGTTGGTCC-3' & & \\
\hline \multirow[t]{2}{*}{ B } & Sense & 5'-TTCTGAGCAGCCTGACTTCTGG-3' & $19267-21989$ & 2,723 \\
\hline & Antisense & 5'-TCTTCTTCTGGTTGAGGC-3' & & \\
\hline \multirow[t]{2}{*}{$\mathrm{C}$} & Sense & 5'-TCAAACCGAGTTACCGTGTTCC-3' & 20448-23276 & 2,829 \\
\hline & Antisense & 5'-TGGGATCCTGACCCAATTCTACTTTCTG-3' & & \\
\hline \multirow[t]{2}{*}{$\mathrm{D}$} & Sense & 5'-TGAAGCTTAGCAAGCAAGGCTTAGAGC-3' & $21879-26627$ & 4,748 \\
\hline & Antisense & 5'-TTAAGCTTCTCCCTCAAGGCTCC-3' & & \\
\hline \multirow[t]{2}{*}{ E } & Sense & 5'-GAGGATCCGAAAGTAGAATTGGGTCAGG-3' & $23243-26627$ & 3,385 \\
\hline & Antisense & 5'-TTAAGCTTCTCCCTCAAGGCTCC-3' & & \\
\hline
\end{tabular}

transferred to nylon membranes (Zeta Probes, Bio-Rad Laboratories, Cambridge, MA). The $\beta$-myosin probe, pSC14, provided by H. P. Vosberg, was labeled to a specific activity of $>10^{9} \mathrm{cpm} / \mu \mathrm{g}$ with $\left[{ }^{32} \mathrm{P}\right] \mathrm{dCTP}$ (Amersham Corp., Arlington Heights, IL) by the random primer procedure of Feinberg and Vogelstein (11). Hybridization and washing conditions were as described previously (5). Following washing the membranes were exposed to X-ray film (XAR-5, Eastman Kodak Co., Rochester, NY) and with Cronex (DuPont Co., Wilmington, DE) intensifying screens at $-80^{\circ} \mathrm{C}$ for $24-72 \mathrm{~h}$.

$P C R$. Cardiac $\beta \mathrm{MHC}$ gene nucleotide sequence (GenBank access no. 52889 [12] and the $\beta / \alpha \mathrm{MHC}$ intergenic region sequence (C. C. Liew, personal communication) were provided by C. C. Liew (University of Toronto, Canada). Based on these sequences several sets of oligonucleotide primers were designed to amplify $\sim 11 \mathrm{~kb}(10,788 \mathrm{bp})$ of the gene and the intergenic region corresponding to that segment detected by $\mathrm{pSC} 14$ probe. The length of the DNA amplified varied from 590 to $4,785 \mathrm{bp}$. The primers used in the PCR reactions that cover the total length of the amplified region are described in Table I. All reactions were done using $150 \mathrm{ng}$ of template DNA from the proband and a normal genomic DNA control, $2 \mu$ l of $10 \times$ Taq polymerase buffer $(500$ $\mathrm{mM} \mathrm{KCl}, 100 \mathrm{mM}$ Tris- $\mathrm{HCl}\left[\mathrm{pH} 9.0\right.$ at $\left.25^{\circ} \mathrm{C}\right], 15 \mathrm{mM} \mathrm{MgCl}_{2}, 0.1 \%$ gelatin [wt/vol] $1 \%$ Triton X-100, Promegal Corp., Madison, WI) 0.5 $\mu \mathrm{M}$ of each primer, $1 \mathrm{U}$ of Taq DNA polymerase (Pharmacia Inc., Piscataway, NJ), and $0.2 \mathrm{mM}$ of dNTP (except for reaction B in which the concentration of dNTP was $0.3 \mathrm{mM}$ ) in a total reaction volume of $20 \mu$ l. DNA thermal cycler (Perkin-Elmer-Cetus, Norwalk, CT) was used to denature at $95^{\circ} \mathrm{C}$ for $3 \mathrm{~min}$ and a subsequent 30-cycle amplification was performed by denaturing at $94^{\circ} \mathrm{C}$ for $1 \mathrm{~min}$, annealing 1 min, and extension at $72^{\circ} \mathrm{C}$ for 3-4 min with a 5-s per cycle increment.
The annealing temperatures for reactions A through $\mathrm{E}$ were $59^{\circ} \mathrm{C}$, $56^{\circ} \mathrm{C}, 55^{\circ} \mathrm{C}, 57^{\circ} \mathrm{C}$, and $54^{\circ} \mathrm{C}$, respectively.

Separation and extraction of PCR products. PCR products were separated using agarose $(0.8-1.0 \%)$ gel electrophoresis. The DNA products were excised from the gel under ultraviolet illumination and extracted using Sephaglas Band Prep kit (Pharmacia, Inc.).

Cloning and sequencing techniques. Restriction endonuclease sites were incorporated at the 5 -end of the primers to yield PCR products with asymmetric restriction sites. The PCR products were digested with the appropriate restriction endonucleases to create cohesive termini and subsequently purified using a Centricon No. 100 ultrafiltration system (Amicon, Beverly, MA). The PCR products with cohesive termini were cloned into a plasmid vector (pGEM) after digestion with the appropriate restriction endonucleases to create compatible termini. Recombinant plasmid DNA was purified by alkaline lysis method (13). Sequencing was performed by the dideoxy sequencing method using a T7 sequencing kit (Pharmacia, Inc.).

RNA extraction. Biopsy samples from biceps muscle were taken after an informed consent was obtained. Samples were immediately frozen at $-70^{\circ} \mathrm{C}$ and subsequently used for extraction of total RNA using the RNAzol method (Biotecx Laboratories, Inc., Houston, TX).

Reverse transcription and first-strand $c D N A$ synthesis. CDNA was synthesized from total RNA by the following method: $0.1 \mu \mathrm{g}$ of total skeletal muscle RNA, $2 \mu$ l of $5 \times$ reverse transcriptase buffer $(250 \mathrm{mM}$ Tris- $\mathrm{HCl}$ [pH 8.3 at room temperature], $375 \mathrm{mM} \mathrm{KCl}, 15 \mathrm{mM} \mathrm{MgCl}{ }_{2}$ [Gibco BRL, Gaitherburg, MD]), and $15 \mu \mathrm{M}$ antisense primer in a total reaction volume of $10 \mu \mathrm{l}$. After denaturing for $5 \mathrm{~min}, 100 \mathrm{U}$ of Moloney murine leukemia virus $\mathrm{RNase} \mathrm{H}^{-}$reverse transcriptase (M-MLV $\mathrm{H}^{-}$RT Superscript, Life Technologies, Inc., Gibco-BRL) $1 \mu$ l of $5 \times \mathrm{RT}$

Table II. Primers Used for Synthesis of First-strand CDNA and RT-PCR

\begin{tabular}{|c|c|c|c|}
\hline $\begin{array}{c}\text { Primer } \\
\text { to }\end{array}$ & & Sequence & Description \\
\hline Exon 40 & Antisense & 5'-TGGATCCGCTACTCCTCATTCAAGCC-3' & $\begin{array}{l}\text { Present in the normal allele and absent in the } \\
\text { mutant allele }\end{array}$ \\
\hline $3^{\prime}-\mathrm{UT}$ & Antisense & 5'-TTTTTTATTCTGGATCCTCCCAAGG-3' & $\begin{array}{l}\text { Present in the normal allele and absent in the } \\
\text { mutant allele }\end{array}$ \\
\hline Second poly A & Antisense & 5'-TTTTTATTTTCATCGTAGGATCCATTACCGC-3' & May be present in the mutant allele \\
\hline Second $3^{\prime}$-UT & Antisense & 5'-TAGGATCCAAATCAGATATAGAAGG-3' & May be present in the mutant allele \\
\hline Oligo $\mathrm{dT}_{12-18}$ & & - & Universal primer \\
\hline Exon 38 & Sense & 5'-AAAAGCTTCTGCGGCTGCAGGACCTGG & $\begin{array}{l}\text { Present in the normal allele and the mutant } \\
\text { allele }\end{array}$ \\
\hline
\end{tabular}



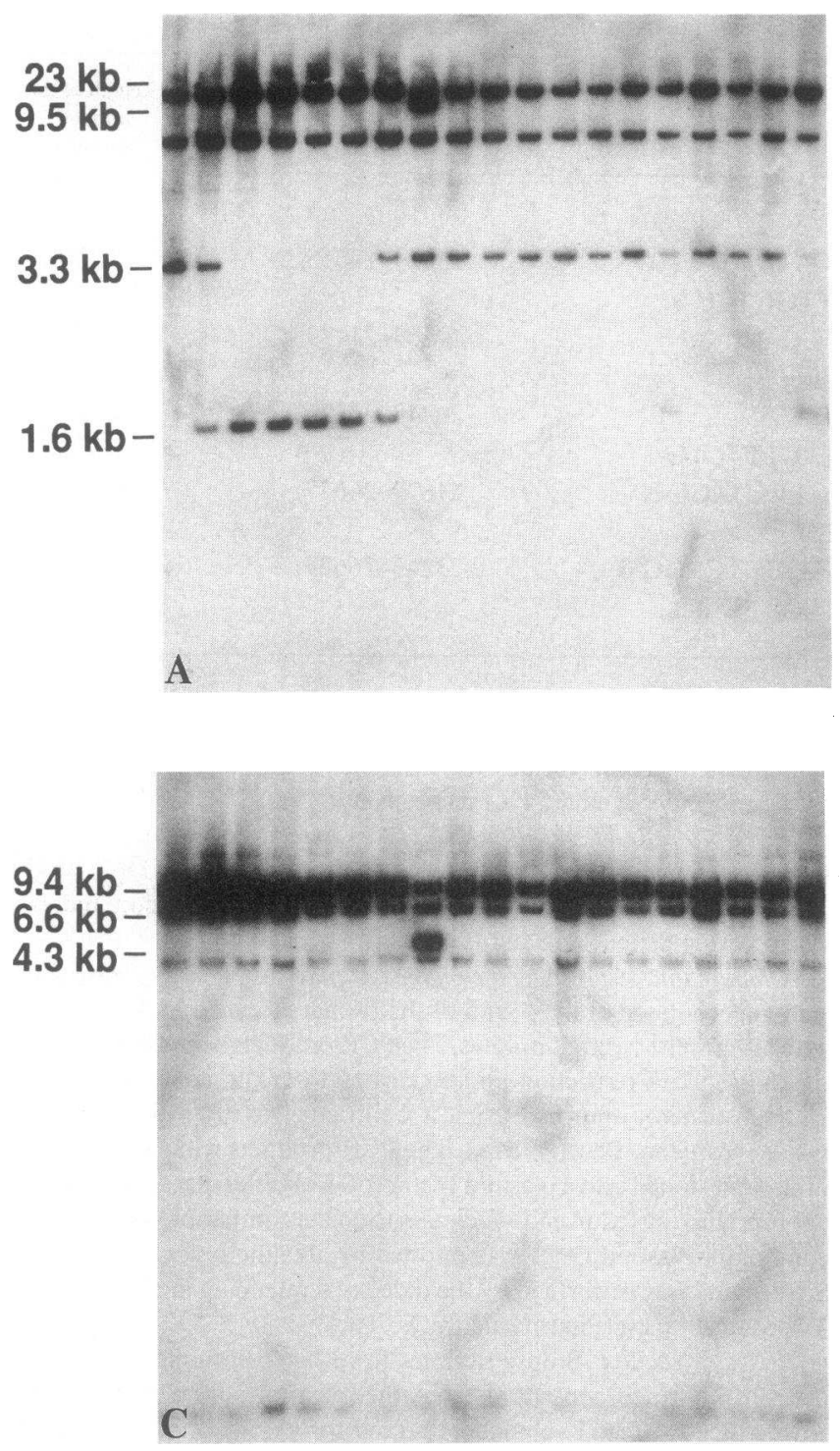

reaction buffer, and $1.5 \mu \mathrm{l}$ of $10 \mathrm{mM}$ dNTP were added in a total reaction volume of $15 \mu \mathrm{l}$. The reaction was incubated at $42^{\circ} \mathrm{C}$ for $2 \mathrm{~h}$ and reverse transcriptase was inactivated at $68^{\circ} \mathrm{C}$ for $20 \mathrm{~min}$. cDNA was stored at $-20^{\circ} \mathrm{C}$ if not used immediately. Antisense primers to exon 40 , polyadenylation signal with $3^{\prime}$-untranslated region, a second polyadenylation signal located $1.7 \mathrm{~kb}$ downstream from the deletion (second polyadenylation primer), the 3'-untranslated region of this polyadenylation signal (second 3'-untranslated primer), and universal oligo $\mathrm{dT}_{12-18}$ primers were used (Table II). cDNA were screened by PCR amplification as follows: cDNA made by the above method was diluted 1:4-fold with $1 \times$ PCR buffer (Promega Corp.) and $12.5 \mu \mathrm{l}$ of the cDNA dilute was added to $12.5 \mu \mathrm{l}$ of PCR mix containing $0.2 \mu \mathrm{M}$ sense primer, $0.2 \mathrm{mM}$ dNTP, 1U Taq DNA polymerase (Pharmacia, Inc.), yielding a final concentration of $0.1 \mu \mathrm{M}$ sense and antisense primer and $0.2 \mathrm{mM}$ dNTP. PCR was done utilizing DNA Thermal Cycler (PerkinElmer-Cetus) in a setting similar to what was described earlier for genomic DNA. The annealing temperature was $55^{\circ} \mathrm{C}$. To amplify cDNA transcribed from the normal allele, a sense primer to exon 38 and an antisense primer to exon 40 or the $3^{\prime}$-untranslated region were used with the appropriate cDNA template in the PCR reactions. In an attempt to amplify cDNA transcribed from the mutant allele a sense primer to exon 38 and an antisense primer to the second polyadenylation signal or 3'-untranslated region or universal oligo dT primers were used in the PCR reactions with the appropriate cDNA template. The

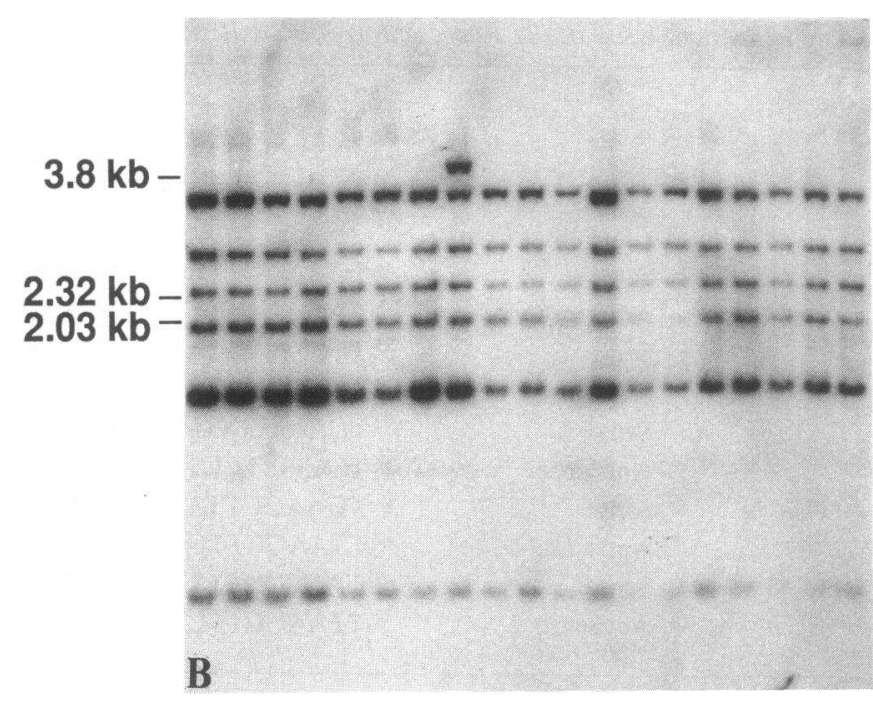

Figure 1. Representative autoradiograms of Southern blots of DNA isolated from probands with FHCM. Restriction endonuclease digests of patients' DNA were probed with the $\beta \mathrm{MHC}$ gene probe, $\mathrm{pSC} 14$. Notice the presence of a $9.5 \mathrm{~kb}(1 A$, lane 8$)$, a $3.8 \mathrm{~kb}(1 \mathrm{~B}$, lane 8$)$, and a $4.3 \mathrm{~kb}(I C$, lane 8$)$ novel restriction fragment endonuclease digests, in the proband from family 151 (lane 8 ).

products of each reaction were identified by gel electrophoresis, extracted from the gel, cloned, and sequenced.

Screening of the $\beta M H C$ gene for other mutations. DNA from the proband was screened for known mutations of the $\beta \mathrm{MHC}$ gene including the $\alpha / \beta \mathrm{MHC}$ hybrid gene, the missense mutation on exon 13 and exon 9 , and in addition remainder of exon 9 as well as exons 7 and 8 were screened by chemical cleavage for potential mutations. Screening for $\alpha / \beta$ MHC hybrid gene was accomplished by Southern blot analysis after BamHI digestion of DNA from family members using a $\beta \mathrm{MHC}$ probe, $\mathrm{pSC} 14$, as described earlier. This probe detects a novel $2.8-\mathrm{kb}$ BamHI restriction fragment if such a fusion gene is present in the proband DNA (7). In the exon 13 missense mutation, an adenine residue substitutes for a guanine residue in coding position 1208 of the $\beta \mathrm{MHC}$ gene and creates an additional Ddel restriction site. The methods of screening for this missense mutation have been published previously (14). In brief, primers were designed to encompass exon 13 of the $\beta$ MHC gene which was amplified by PCR. The PCR product (154 bp) was separated by gel electrophoresis, identified by ethidium bromide staining, excised from the gel, and purified. The purified PCR product was subjected to Ddel digestion.

The known missense mutation in exon 9 consists of a guanine residue at coding position 832 (exon 9) which is replaced by an adenine residue. Using chemical cleavage, we screened for this mutation and also for potential unknown mutations in the remainder of exon 9 and 

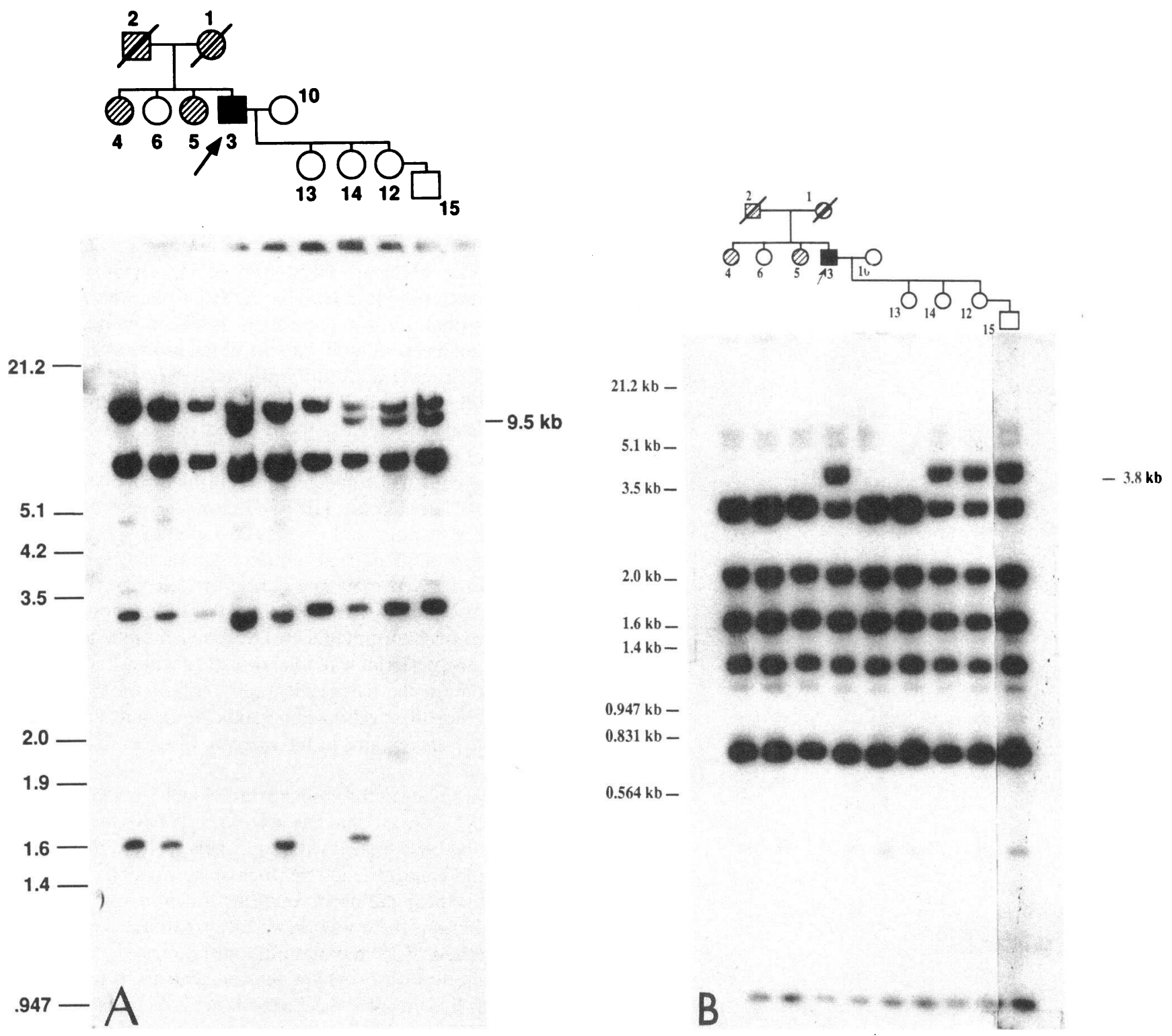

$.947-\mathrm{A}$

Figure 2. Pedigree of family 151 and the corresponding Southern blots of DNA digests with BamHI, TaqI, and HindIII detected by pSC14 probe. The BamHI $(9.5 \mathrm{~Kb})$, TaqI $(3.8 \mathrm{~Kb})$, and HindIII $(4.3 \mathrm{~Kb})$ novel restriction fragments are present in the proband and three additional members of the family. Open circles and squares represent clinically unaffected female and male gender, respectively. Closed circles or squares indicate clinically affected females or males. Hatched circles or squares indicate "uncertain" diagnosis and slash indicates deceased individuals.

exons 7 and 8 (15). The technique of chemical cleavage detects nucleotide mismatches in heteroduplexes composed of a normal DNA strand and its complementary test strand. This technique is also useful to detect other mutations such as deletions and insertions. Nucleotide mismatches occurring with cytosine residues are detectable after the hydroxylamine reaction. Mismatch thymine residues are detectable after the osmium tetroxide reaction. Chemical cleavage was performed as follows: The region of the $\beta \mathrm{MHC}$ gene encompassing exons 7 through 9 was amplified by PCR. The PCR reaction contained $250 \mathrm{ng}$ of the template DNA, $0.2 \mu \mathrm{M}$ of each primer, $10 \mathrm{mM}$ Tris $\mathrm{HCl}(\mathrm{pH}$ 8.3 ), $50 \mathrm{mM} \mathrm{KCl}, 0.001 \%$ (wt/vol) gelatin, $1.5 \mathrm{mM} \mathrm{MgCl}, 200 \mu \mathrm{M} 4$ dNTP, and $1 \mathrm{U}$ of TaqI DNA polymerase (Pharmacia Inc., 5,000 U/ $\mathrm{ml}$ ). Thermal cycling parameters were: denaturing at $94^{\circ} \mathrm{C}$ for $3 \mathrm{~min}$; followed by 30 cycles of denaturing at $94^{\circ} \mathrm{C}$ for $1 \mathrm{~min}$, annealing at $58^{\circ} \mathrm{C}$ for $30 \mathrm{~s}$, and extension at $72^{\circ} \mathrm{C}$ for $30 \mathrm{~s}$, with a final extension at $72^{\circ} \mathrm{C}$ for $3 \mathrm{~min}$. The amplified PCR products were isolated by gel electrophoresis and were excised and extracted as described above. A secondary amplification of the extracted product was performed using conditions described by Kogan et al. (16) and the same cycling parameters as in the primary amplification. The reamplified PCR product was extracted from the gel in a manner as described above. A sense and an antisense ${ }^{32} \mathrm{P}$ end-labeled probe were produced using end-labeled sense and antisense primers in separate reactions to amplify the region of interest from normal DNA. Sense and antisense labeled heteroduplexes were formed by mixing $\sim 3 \times 10^{5} \mathrm{cpm}$ of each labeled probe separately with each secondary PCR product being tested and denaturing the mixture at $100^{\circ} \mathrm{C}$ for $3 \mathrm{~min}$, and subsequent reannealing the strands at $42^{\circ} \mathrm{C}$ for $2 \mathrm{~h}$. The reannealed heteroduplexes were isolated by ethanol precipitation and resuspended in $20 \mu \mathrm{l}$ of $\mathrm{H}_{2} \mathrm{O}$ for use in the chemical reactions.

Hydroxylamine reaction was as follows: a $6 \mu$ l aliquot of each heteroduplex was mixed with $20 \mu \mathrm{l}$ of $2.5 \mathrm{M}$ hydroxylamine and incubated at $37^{\circ} \mathrm{C}$ for $1 \mathrm{~h}$. The reaction was stopped by adding an excess of yeast carrier RNA and the heteroduplexes were isolated by ethanol precipita- 

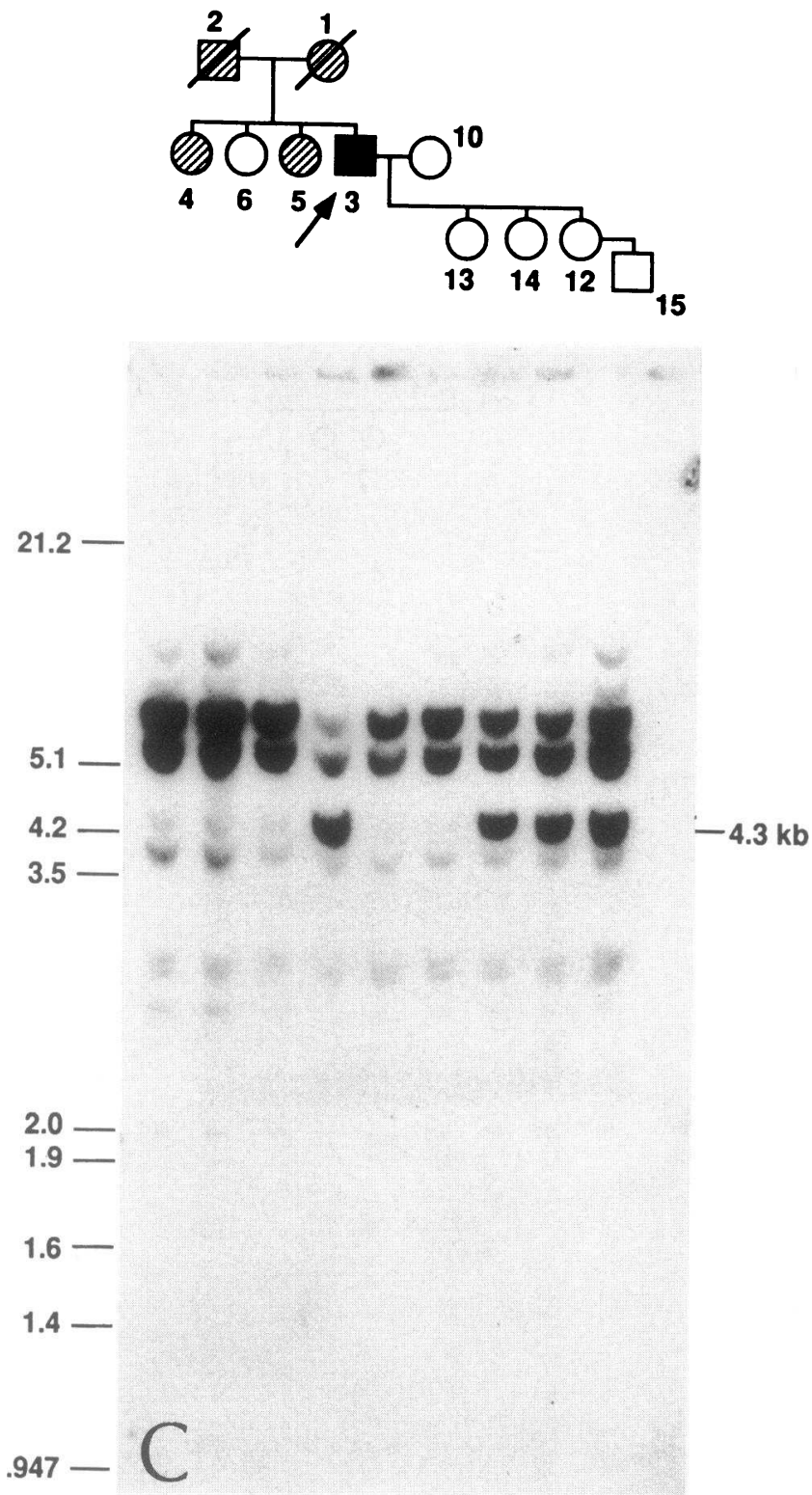

Figure 2 (Continued)

tion, washed, and lyophilized. Osmium tetroxide reaction: a $6 \mu \mathrm{l}$ aliquot of each heteroduplex was mixed with $15 \mu$ l of $2 \% \mathrm{OsO}_{4}$ in $10 \mathrm{mM}$ Tris $\mathrm{HCl}(\mathrm{pH} \mathrm{7.7),} 1 \mu \mathrm{M}$ EDTA ( $\mathrm{pH} \mathrm{8.0)}$ ), and 1.5\% (vol/vol) pyridine and incubated at $37^{\circ} \mathrm{C}$ for $5 \mathrm{~min}$. The reaction was stopped and the heteroduplexes isolated as described above. The lyophilized products were mixed with $50 \mu \mathrm{l}$ of $1.0 \mathrm{M}$ piperidine and incubated at $90^{\circ} \mathrm{C}$ for 30 $\mathrm{min}$. The mixture was quickly cooled on ice, and the cleavage products were ethanol precipitated and lyophilized. Chemical cleavage products were resuspended in formamide and electrophoresed on a $12 \%$ denaturing polyacrylamide gel. An autoradiogram was developed from the gel for detection of base mismatches in the heteroduplexes using conventional methodology.

\section{Results}

Clinical characteristics. The pedigree of this family has been depicted on the upper portion of Fig. 2 (q.r.). The proband is a $67-y r-o l d$ male diagnosed at age of 59 , when he presented with symptoms of atypical chest pain, lightheadedness, and decreased exercise tolerance. On cardiac examination we detected a S4 and a grade III/VI systolic ejection murmur at mid left sternal border. Electrocardiography (EKG) showed normal sinus rhythm and left ventricular hypertrophy with repolarization abnormalities. Analysis of recordings of two 24-h Holter monitoring intervals showed sinus rhythm with premature atrial and ventricular beats and short runs of ventricular bigeminy. A two-dimensional echocardiogram showed moderate concentric ventricular hypertrophy with septal and posterior wall thickness of $2 \mathrm{~cm}$, a left ventricular ejection fraction of $60-69 \%$, and systolic anterior motion of the anterior leaflet of the mitral valve. There was also a $25 \mathrm{mmHg}$ left ventricular outflow tract gradient. Right ventricular endomyocardial biopsy showed mild hypertrophic cardiac fibers with minimal focal interstitial fibrosis. The patient has been treated with $\beta$ blockers and has done well. Parents of the proband died $37 \mathrm{yr}$ ago, and their medical history is not available.

The proband has three siblings and the clinical data of these individuals are provided as follows: Individual 4 is $77 \mathrm{yr}$ old and has not experienced any cardiac symptoms. Her past medical history consists of pancreatitis, gall bladder disease, and degenerative joint disease. Her EKG showed sinus bradycardia at the rate of $56 \mathrm{bpm}$, and left axis deviation of -40 . A recent chest X-ray showed mild left ventricular prominence. An echocardiogram showed moderate concentric left ventricular hypertrophy with normal left ventricular systolic function, moderately enlarged left atrium $(4.6 \mathrm{~cm})$, ventricular septal thickness of $1.7 \mathrm{~cm}$, and posterior wall thickness of $1.6 \mathrm{~cm}$. Although this individual meets the echocardiographic criteria for HCM, one cannot exclude these echocardiographic findings as due to age alone. Thus, she remains in the category of diagnosis "uncertain."

Another sibling of the proband, individual 5, has symptoms of exertional dyspnea. She has been hypertensive for the past $20 \mathrm{yr}$ and has been treated with $\beta$ blockers. Echocardiography showed mild concentric left ventricular hypertrophy with 1.3 $\mathrm{cm}$ wall thickness and normal systolic function and chamber size. In addition, there was also a localized basal ventricular septal thickness of $18 \mathrm{~mm}$ and mild mitral regurgitation. Due to long-standing history of hypertension, which may be responsible for the hypertrophy, the diagnosis of HCM in this individual remains "uncertain." Individual 6 is a 63-yr-old female and is asymptomatic with a normal echocardiogram. Individual 13, a 35-yr-old female, is currently asymptomatic, and is normal on physical examination. Echocardiography showed normal left ventricular function with ventricular septal thickness of 1.1 $\mathrm{cm}$ and posterior wall thickness of $1.0 \mathrm{~cm}$. However, systolic anterior motion of the mitral valve chordae was noted on echocardiogram. Individual 12, a 33-yr-old female, is asymptomatic with a normal EKG and echocardiogram. Individual 14, a 32-yr-old male, is asymptomatic with a normal physical examination. EKG and echocardiography are both normal with a septal thickness of $0.9 \mathrm{~cm}$ and posterior wall thickness of 1.0 $\mathrm{cm}$. Individual 15, a 10-yr-old, is asymptomatic and has a normal echocardiogram. Individuals 10 and 11 (spouses) are both asymptomatic and have normal echocardiograms (individual 11 is not shown in the pedigree).

Southern blotting analysis. In order to detect large DNA rearrangements in the MHC gene of individuals with FHCM Southern blot analysis was performed on DNA from a total of 59 probands using the $\beta$-myosin probe, pSC14. This probe detects a two-allele BamHI restriction length polymorphism of 3.3 and $1.6 \mathrm{~kb}$ with a frequency of 0.7 and 0.3 , respectively (17). Representative autoradiograms of Southern blot analysis 

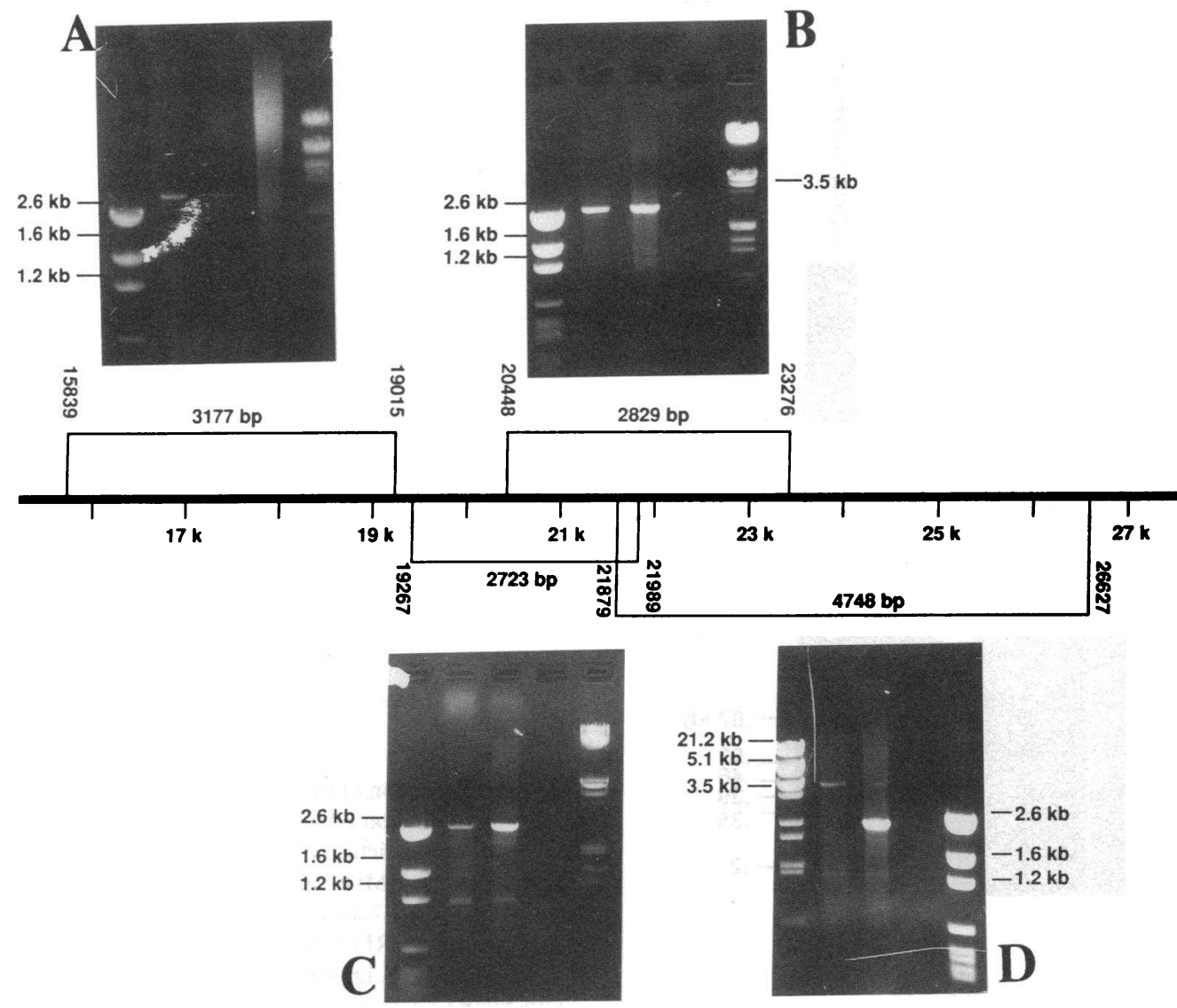

Figure 3. Segments of the $\beta$ MHC gene amplified by PCR and the corresponding pictures of the PCR products' gel electrophoresis. In each photograph, lane 1 represents a DNA size marker, lane 2 a normal DNA template, lane 3 DNA template from the proband, and lane $4 \mathrm{a}$ negative control. PCR products are similar in size (in reactions $A, B$, and $C$ ) except for the products from the 3'end of the $\beta M H C$ gene (reaction D) which shows an additional $2.3-\mathrm{kb}$ product in the DNA template from the proband. of DNA isolated from FHCM probands are shown in Fig. 1. In addition to the expected RFLP and two constant fragments a novel 9.5-kb BamHI restriction fragment was detected by the pSC 14 probe in a single proband from family 151 (Fig. $1 A$, lane 8 ). The genomic DNA from all 59 probands was also digested with TaqI and HindIII restriction endonucleases and probed with pSC14. A novel 3.8-kb and a novel 4.3-kb restriction fragment in TaqI and HindIII digests, respectively, were detected (Fig. $1 B$, lane 8 and $1 C$, lane 8 ) in the digest of DNA from the proband of family 151 . This polymorphism was not present in any of the other 58 probands of families with FHCM, nor was it present in 73 unrelated normal individuals. DNA from additional family members of pedigree 151 was digested with BamHI, TaqI, and HindIII and probed with pSC14. Three additional members from two subsequent generations also had the identical novel restriction fragments on Southern blots, indicating the co-dominant Mendelian inheritance of this polymorphism. Pedigree 151 together with the corresponding Southern blots of their DNA digests with BamHI, TaqI, and HindIII are shown in Fig. 2.

$P C R$ analysis. The recognition of a unique restriction fragment by the pSC14 probe in the proband DNA indicated the presence of a mutation involving the region of the $\beta \mathrm{MHC}$ gene detected by the pSC14 probe (introns 29-37) or the vicinity of this region. Several sets of primers were designed to amplify $\sim 11 \mathrm{~kb}(10,788 \mathrm{bp})$ of the $\beta \mathrm{MHC}$ gene in segments from 590 to 4,785 nucleotides in length encompassing exons 29-40.

The PCR products using DNA from the HCM pedigree 151 proband as template were compared with the PCR product of a normal DNA template by gel electrophoresis and restriction mapping. The PCR products from the proband and the normal control were identical in length and restriction map in all segments (reactions A, B, and C) except for the 3'- end of the $\beta \mathrm{MHC}$ gene (reaction D). PCR amplification of this segment using primers to amplify from nucleotide 21,879 (in intron 37) through nucleotide 26,627 (intergenic region between $\beta \mathrm{MHC}$ and $\alpha \mathrm{MHC}$ genes) produced an unexpected 2.3-kb product in the proband DNA, in addition to the expected product of 4.7 $\mathrm{kb}$ which was present from both the normal DNA and the proband DNA (Fig. 3). This implied a deletion, $2.4 \mathrm{~kb}$ in size $(4.7 \mathrm{~kb}-2.3 \mathrm{~kb})$, in one $\beta$-myosin allele of the proband genome. In order to further delineate the location of this deletion, the published restriction map of the $\beta \mathrm{MHC}$ gene sequence (12) and the restriction map of the $\beta / \alpha \mathrm{MHC}$ intergenic resion (C. C. Liew, personal communication) were reviewed, in the region of the 4.7-kb product which showed absence of restriction sites for BamHI, HindIII, or TaqI restriction endonucleases, but the presence of two restriction sites for EcoRI restriction endonuclease. Digestion of the 4.7-kb product with EcoRI restriction endonuclease showed three products of $3.4 \mathrm{~kb}$ and 844 and 507 bp while digestion of the $2.3-\mathrm{kb}$ product with the EcoRI restriction endonuclease produced three products of $1 \mathrm{~kb}, 844 \mathrm{bp}$, and 507 bp (Fig. 4), the last two identical to the normal map and the $1-\mathrm{kb}$ product being a truncated product of the $3.4-\mathrm{kb}$ product. Comparison of these products with the restriction map of the normal $\beta M H C$ gene and the $\beta / \alpha$ intergenic region ( 12 ; C. C. Liew, personal communication) identified the orientation of these products in the normal genomic DNA, such that the 507-bp fragment and the 844-bp fragment were located upstream to the 3.4-kb fragment and the 3.4-kb product was 


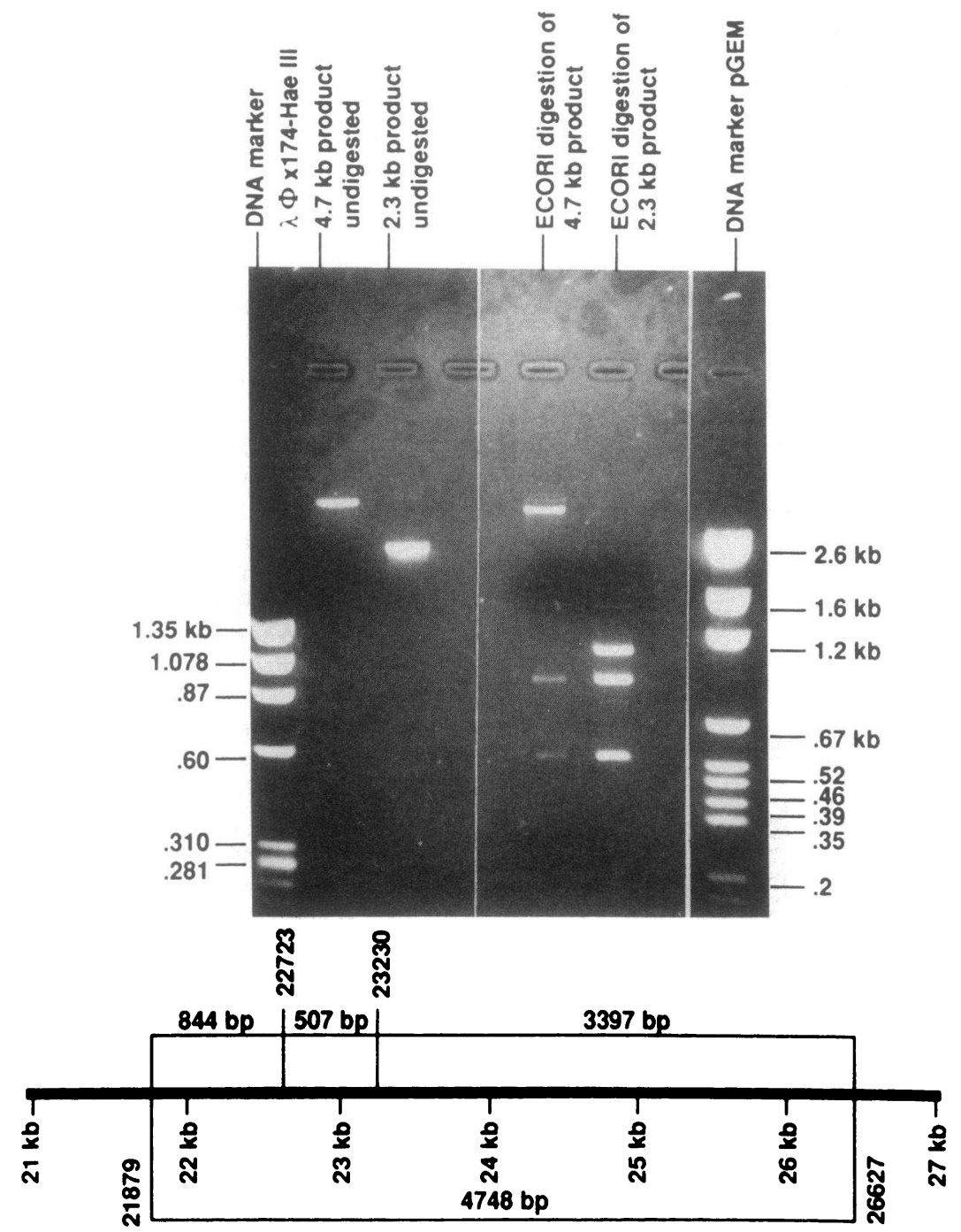

Figure 4. Digestion of the 4.7- and 2.3-kb products (from PCR reaction $D$ ) with EcoRI restriction endonuclease. Restriction enzyme map of the $\beta \mathrm{MHC}$ gene and the $\beta / \alpha \mathrm{MHC}$ intergenic region in the segment of the $4.7-\mathrm{kb}$ product shows two restriction sites for EcoRI restriction enzyme at positions 22723 and 23230 . Digestion of the 4.7-kb product with EcoRI restriction endonuclease produced three fragments of $844 \mathrm{bp}, 507 \mathrm{bp}$, and $3.4 \mathrm{~kb}$; while digestion of the $2.3-\mathrm{kb}$ product with EcoRI restriction endonuclease produced two similar products ( 844 and $507 \mathrm{bp}$ ) and a 1-kb product, indicating that the $1-\mathrm{kb}$ fragment is a truncated form of the 3.4-kb fragment. the amplified segment between nucleotide 23,230 of $\beta \mathrm{MHC}$ and nucleotide 26,627 of the $\beta / \alpha \mathrm{MHC}$ intergenic region. Therefore, a new set of primers were designed to flank this region and amplification with PCR (reaction E) produced the expected 3.4-kb product from normal DNA template and proband DNA template, and an additional $1-\mathrm{kb}$ product in the proband DNA. PCR amplification of DNA isolated from all members of the pedigree 151 was performed and the 1-kb product was found to be present in those family members with the novel restriction fragments on Southern blot (Fig. 5).

Cloning and sequencing analysis. To precisely localize the extent of the observed deletion, PCR primers with the asymmetric internal restriction sites at the $5^{\prime}$ ends flanking the deletion were used to amplify this region of the DNA from the proband. The PCR product was cloned into pGEM4Z and sequenced. The sequence analysis revealed a $2.4-\mathrm{kb}$ deletion extending from nucleotide 23,793 of the $\beta \mathrm{MHC}$ gene through nucleotide 26,171 of the intergenic region, between $\alpha$ - and $\beta M H C$ genes, which includes part of intron 39 , and all of exon 40 which contains the coding sequence for the $3^{\prime}$ carboxy terminal amino acids as well as the entire $3^{\prime}$ untranslated region (Fig. 6). The deletion extends 1,833 nucleotides into the region $5^{\prime}$ to the $\alpha \mathrm{MHC}$ gene. The deleted region is flanked by a 45 -bp direct repeat with $96 \%$ positional identity in the normal allele. The downstream repeated sequences are deleted in the mutant allele.

Transcription analysis. In an attempt to determine whether mRNA for the mutant $\beta$ MHC gene allele is transcribed we performed reverse transcription PCR (RT-PCR) on mRNA extracted from a biceps muscle biopsy obtained from the proband of pedigree 151. After extraction of total RNA from the biopsy sample, cDNA for the normal allele was made using reverse transcriptase with the antisense primer to exon 40 and subsequently amplified by PCR using an exon 38 sense primer. This yielded the expected product of $239 \mathrm{bp}$ (Fig. 7) which was cloned, sequenced, and confirmed to be a transcription product of the normal allele. A potential second polyadenylation signal sequence is located $1.7 \mathrm{~kb}$ downstream from the $3^{\prime}$-end of the deletion in the $\beta / \alpha$ myosin intragenic region (Fig. 6). We attempted to make first-strand cDNA from the abnormal allele using antisense primers to the second polyadenylation signal, second 3'-untranslated region, and oligonucleotide dT primer. Using these different primers we were consistently unsuccessful in obtaining any RT-PCR product.

Screening for other mutations in the $\beta M H C$ gene. Southern blot analysis showed the normal pattern of two polymorphic 


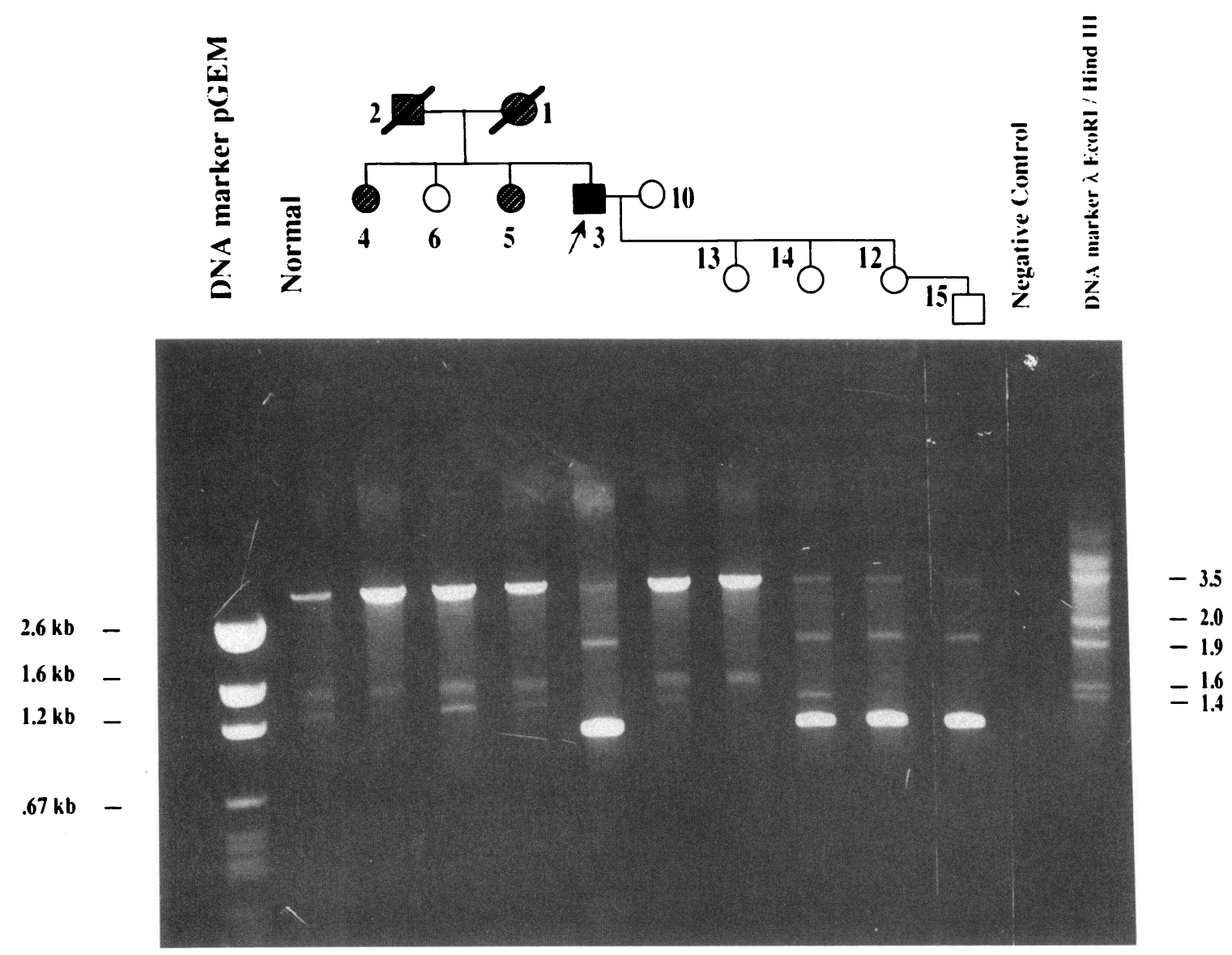

Figure 5. Photograph of gel electrophoresis of the PCR products of reaction E in members of family 151 and the corresponding pedigree. The expected product size is $3.3 \mathrm{~kb}$. Notice the presence of a $1 \mathrm{~kb}$ product in the proband and three additional members of this family. Open circles and squares represent clinically unaffected female and male gender, respectively. Closed circles or squares indicate clinically affected females or males. Hatched circles or squares indicate "uncertain" diagnosis and slash indicates deceased individuals.

bands of 3.3 and $1.6 \mathrm{~kb}$, two constant fragments, and a novel 9.5-kb restriction fragment, when probed with pSC14. The 2.8$\mathrm{kb}$ novel BamHI restriction fragment indicating the presence of an $\alpha / \beta \mathrm{MHC}$ hybrid gene was not present (7).

Electrophoretic analysis of the PCR amplified exon 13 of the $\beta \mathrm{MHC}$ gene showed a PCR product of $154 \mathrm{bp}$ in size which, upon digestion, resulted in two fragments of 84 and $70 \mathrm{bp}$, indicating that the missense mutation was not present. Had the mutation been present, the DNA would have contained four fragments of $84,70,52$, and $32 \mathrm{bp}$ (14) owing to the presence of both the normal and abnormal alleles.

Chemical cleavage of exons 7,8 , and 9 of the $\beta \mathrm{MHC}$ gene showed no mismatches between the labeled normal strand and its complementary test strand. Because both the sense and antisense strands were labeled and analyzed separately, these results indicate the absence of the known missense mutation in

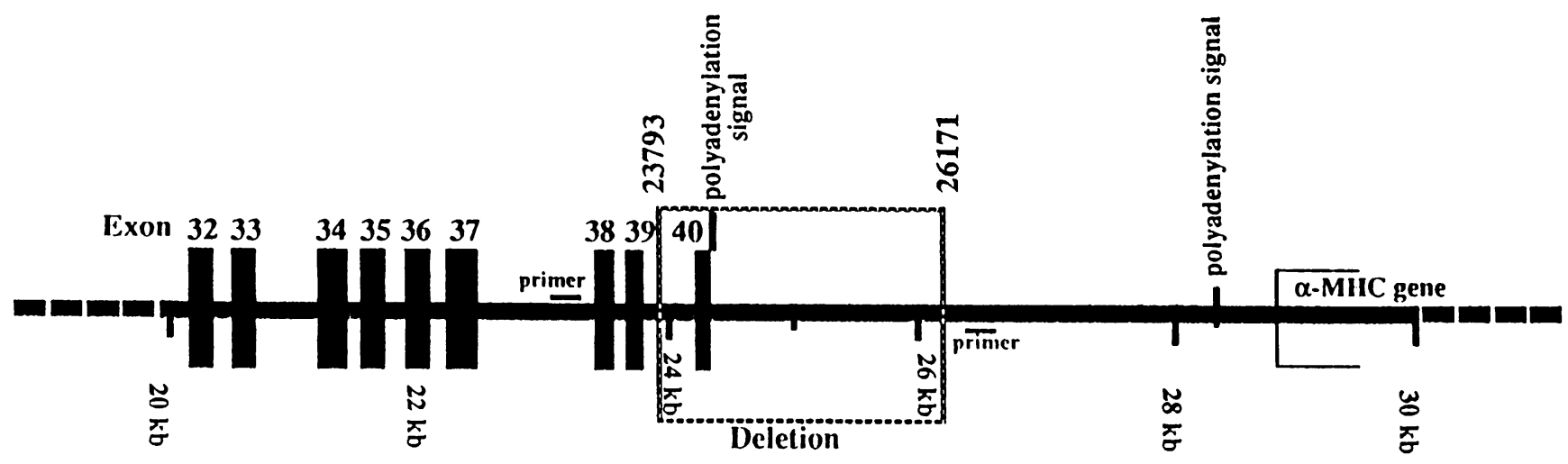

Figure 6. Diagram showing the location of the deletion in the $\beta$ MHC gene. Deletion involves part of intron 39, exon 40, including 3'-untranslated region and the polyadenylation signal. It also extends $1.8 \mathrm{~kb}$ into the $\beta / \alpha$ intergenic region. 


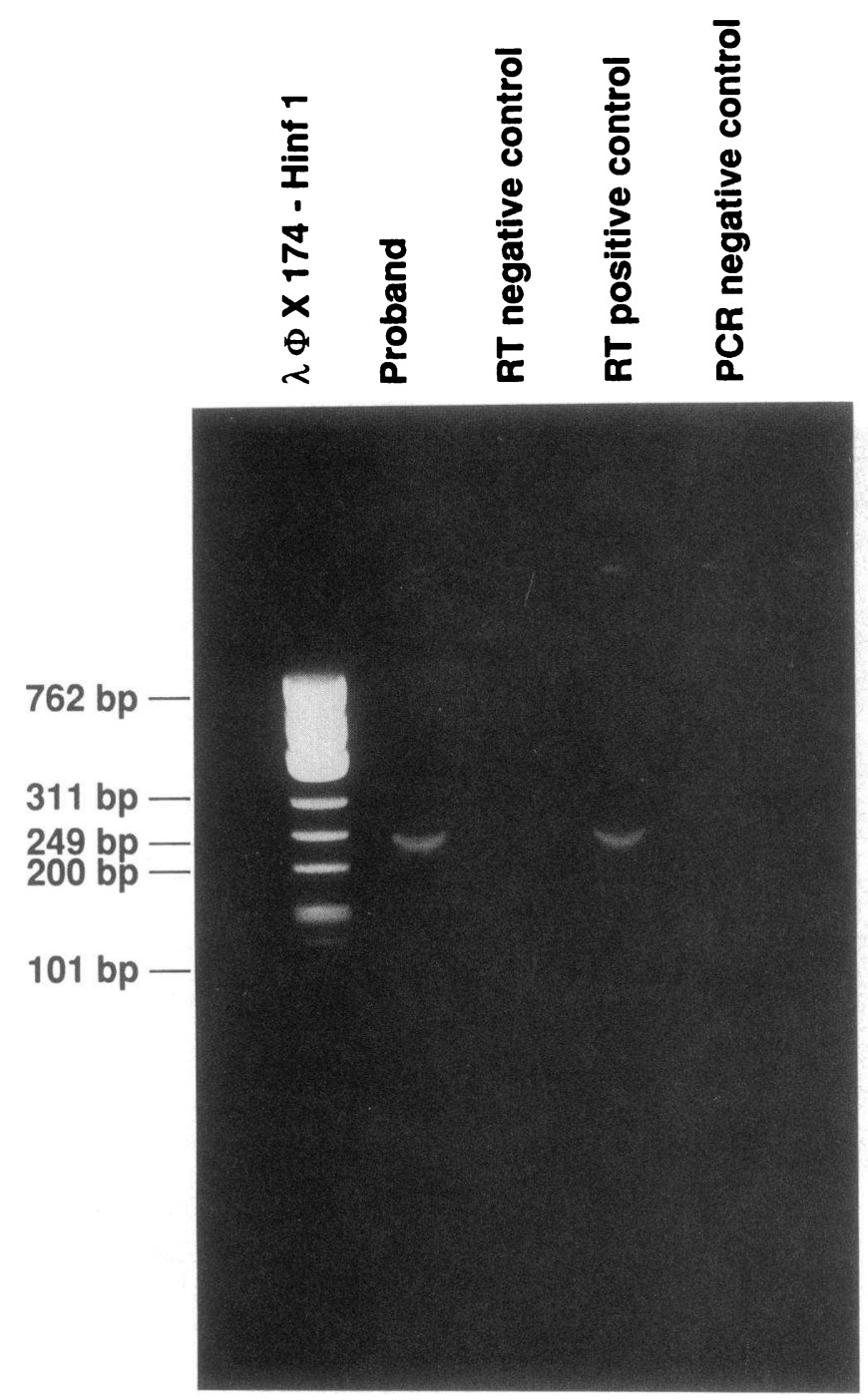

Figure 7. Transcription of the normal allele. RT-PCR using sense primer to exon 38 and antisense primer to exon 40 (present in the normal allele and absent in the mutant allele) yielded the expected product of $239 \mathrm{bp}$, indicating the transcription of the normal allele.

exon 9 as well as showing no other mutations in the remainder of exon 9 or in exons 7 and 8 .

\section{Discussion}

We have detected a $2.4-\mathrm{kb}$ deletion in the $3^{\prime}$-end of the $\beta$-myosin gene in the proband of a small family with HCM. The deleted portion of the $\beta \mathrm{MHC}$ gene includes a part of intron 39 , all of exon 40 which contains coding sequences for the five carboxy terminal amino acids, the entire 3 '-untranslated region and a portion of the region between the $\beta$ - and $\alpha \mathrm{MHC}$ genes. The deletion is flanked by $45-b p$ direct repeat sequences and the distal repeat sequences are deleted in the mutant allele. Such flanking direct repeat sequences are believed to mediate deletion mutations.

The deletion mutation was inherited in a Mendelian fashion in two subsequent generations of the family. However, none of the three additional family members with the deletion could be shown to have HCM by the clinical diagnostic criteria used in this study. We cannot rule out the possibility that each of these individuals will develop the disease later in life as HCM is characterized by variable penetrance and variable expressivity. These results demonstrate the difficulty which may be encountered in differentiating sporadic HCM from familial HCM in small kindreds. Clinical criteria alone may not be sensitive enough to identify all affected family members and genetic diagnosis is not yet available for all HCM mutations. In two other individuals of the family, the diagnosis of HCM remains uncertain because, while they have ventricular hypertrophy they also have other potential causes for this such as hypertension.

We are concerned that in none of the three offsprings is there evidence of HCM despite having inherited the defect. It is possible that the disease in the proband is due to mutations other than the deletion in the $3^{\prime}$ end of the $\beta$ MHC gene described above. Based on our analysis with RFLP and that of PCR, we have excluded any other mutation that would have involved significant rearrangement in the $\beta \mathrm{MHC}$ gene. The known mutations of the $\beta \mathrm{MHC}$ gene, the $\alpha / \beta \mathrm{MHC}$ hybrid gene, and the missense mutations in exons 9 and 13, were excluded (7-9). In addition, the results of chemical cleavage analysis showed no mutations in exons 7, 8, and 9. Screening of the whole $\beta \mathrm{MHC}$ gene for single nucleotide mutations by a technique such as chemical cleavage (the most sensitive) may require years of study, considering that the $\beta \mathrm{MHC}$ gene is $24 \mathrm{~kb}$ in length. It is not possible to perform linkage analysis to confirm a chromosome 14 disease locus in this family due to its small size. Collection of several families may be difficult because it would appear that this deletion mutation is not a common cause of FHCM. We have examined 59 probands and only one proband had the deletion mutation.

Our unsuccessful attempts to demonstrate transcription from the mutant allele do not exclude production of a mutant mRNA. Our failure to detect a transcript using RT PCR amplification may have resulted from the inability to choose the correct antisense primer for reverse transcription from the mutant mRNA for first-strand cDNA synthesis since all potential splice junctions cannot be cleaved from DNA sequence analysis. It is not evident from DNA sequence analysis where transcription of the mutant allele if it is made would terminate. We chose to make an antisense primer complementary to the sequence around and including a polyadenylation signal $\sim 1.7$ $\mathrm{kb}$ downstream from the 3 -end of the deletion. This is the first polyadenylation sequence downstream from the end of the deletion. In addition, a second antisense universal oligo dT primer was used to prime cDNA synthesis which was also without success. The other possibility is the low abundance and/or instability of the mutant mRNA eluded isolation and detection by PCR and electrophoretic analysis.

It is, thus, not possible given the small size of the family, the insensitivity of clinical diagnosis, and the inability to detect a transcript from the mutant allele to conclusively prove that the deletion mutation is responsible for the HCM in this family. Whether the deletion is responsible for the disease is further complicated by the observation that the proband did not develop symptoms of HCM until the age of 59, and the two offsprings are only 32 and 33 yr of age. The grandson shows no clinical or echocardiographic evidence of FHCM but is only 10 $\mathrm{yr}$ of age. Thus, if indeed the deletion is responsible for the disease in the proband, given this exaggerated form of age-de- 
pendent penetrance, one cannot exclude the possibility that the offspring may, in the future, develop the disease. These observations coupled with a family whose size precludes linkage analysis prohibits a definitive interpretation as to whether this deletion is responsible for the disease in the proband.

It is interesting to speculate how this mutation might produce HCM. Studies of the Caenorhabditis elegans unc-54 gene, which encodes the major body wall muscle myosin isoform $\beta \mathrm{MHCB}$, have shown that a mutation that deletes the 3 '-untranslated region (18) apparently results in an unstable mRNA (19) that produces small quantities of protein product. Recent unpublished studies in $C$. elegans $(\mathrm{R}$. H. Waterston, personal communication) have tested the function of a myosin construct in which an introduced ochre codon results in a truncated protein lacking the last nine residues of the carboxyl-terminal rod as well as the entire 23-residue nonhelical tailpiece. When this construct is introduced into $C$. elegans, it produces a dominant mild unc phenotype, apparently interfering with the incorporation of normal myosin into the sarcomere (R. H. Waterston, personal communication). The deletion mutation in this family also appears to produce a mild form of HCM. This may be because transcription from the mutant allele produces an unstable mRNA as a result of the loss of the polyadenylation signal sequence. This instability leads to only a small amount of mutant protein from the unstable message which would lack the five terminal amino acids and would be expected to disrupt sarcomere assembly or function. In that only a minute quantity of mutant protein may be synthesized, it is expected that only a subset of sarcomeric assembly and function will be disrupted resulting in a mild, dominant phenotype. While it is not possible given the limitations discussed above to prove that the 2.4$\mathrm{kb}$ deletion is the cause of HCM in this family these results suggest testable hypotheses for the role of the carboxyl terminus of $\beta$-myosin in sarcomere assembly and function. It is intriguing that such a large deletion, involving $10 \%$ of the gene, is inherited in subsequent generations in which individuals may or may not be affected, and those that are affected, not until much later in life. Does this mean that only the normal allele is being translated? If so, why so? Expression of mutant $\beta \mathrm{MHC}$ gene constructs in appropriate experimental systems will permit us to examine the role of the 3 -untranslated sequences and polyadenylation on the stability of $\beta$-myosin mRNA. Expression of an in-frame deletion of the carboxyl-terminal amino acids will provide insights to the role of these amino acids on the assembly and function of mammalian sarcomeres. We are currently designing studies to examine these questions.

\section{Acknowledgments}

We would like to express our gratitude to Dr. Robert H. Waterston for critical review of the manuscript and permission to quote unpublished data, Dr. C. C. Liew for providing the sequence of intergenic region between $\beta$ - and $\alpha \mathrm{MHC}$ genes, Dr. Tony S. Ma for helpful discussions, Grace Czernuszewicz and Terry Tapscott for technical assistance, and Debora Weaver, Alexandra Pinckard, and Sherry Terry for manuscript and figure preparation.
This work is supported in part by grants from the National Heart, Lung, and Blood Institute, Specialized Centers of Research (P50HL42267-01), and the American Heart Association, Bugher Foundation Center for Molecular Biology (86-2216).

\section{References}

1. Maron, B. M., S. E. Epstein, and W. C. Roberts. 1986. Causes of sudden death in competitive athletes. J. Am. Coll. Cardiol. 7:204-214.

2. Sasson, A., H. Rakowski, and E. D. Wigle. 1988. Hypertrophic cardiomyopathy. Cardiol. Clin. 6:233:288.

3. Jarcho, J. A., W. P. McKenna, J. A. Pare, S. D. Solomon, R. F. Holcombe, S. Dickie, T. Levi, H. Donis-Keller, J. G. Seidman, and C. E. Seidman. 1989. Mapping a gene for familial hypertrophic cardiomyopathy to chromosome $14 \mathrm{q} 1$. N. Engl. J. Med. 321:1372-1378.

4. Solomon, S. D., A. A. T. Geisterfer-Lowrance, H.-P. Vosberg, G. Hiller, J. A. Jarcho, C. C. Morton, W. O. McBride, A. L. Mitchell, A. E. Bale, W. J. McKenna, et al. 1990. A locus for familial hypertrophic cardiomyopathy is closely linked to the cardiac myosin heavy genes, CR1-L436, and CRI-L329 on chromosome 14 at q11-912. Am. J. Hum. Genet. 47:389-394.

5. Hejtmancik, J. F., P. A. Brink, J. Towbin, R. Hill, L. Brink, T. Tapscott, A Trakhtenbroit, and R. Roberts. 1991. Localization of gene for familial hypertrophic cardiomyopathy to chromosome $14 \mathrm{q} 1$ in a diverse U.S. population. Circulation. 83:1592-1597.

6. Solomon, S. D., J. A. Jarcho, W. McKenna, A. Geisterfer-Lawrence, R. Germain, R. Salerni, J. G. Seidman, and C. E. Seidman. 1990. Familial hypertrophic cardiomyopathy is a genetically heterogeneous disease. J. Clin. Invest. 86:993-999.

7. Tanigawa, G., J. A. Jarcho, S. Kass, S. D. Solomon, and C. E. Seidman. 1990. A molecular basis for familial hypertrophic cardiomyopathy: an alpha/beta cardiac myosin heavy chain hybrid gene. Cell. 62:991-998.

8. Geisterfer-Lawrance, A. A., S. Kass, G. Tanigawa, H.-P. Vosberg, W. McKenna. C. E. Seidman, and J. G. Seidman. 1990. A molecular basis for familial hypertrophic cardiomyopathy: A beta-cardiac myosin heavy chain gene missense mutation. Cell. 62:999-1006.

9. Rosenzweig, A., H. Watkins, D. Hwang, M. Miri, W. McKenna, T. Traill, J. G. Seidman, and C. E. Seidman. 1991. Preclinical diagnosis of familial hypertrophic cardiomyopathy by genetic analysis of blood lymphocytes. $N$. Engl. J. Med. 325:1753-1760.

10. Neitzel, N. 1986. A routine method for the establishment of permanent growing lymphoblastoic cell lines. Hum. Genet. 73:320-326.

11. Feinberg, A. P., and B. A. Vogelstein. 1983. A technique for radiolabelling DNA restriction endonuclease fragments to high specific activity. Anal. Biochem. 132:6-13.

12. Liew, C. C., M. J. Sole, K. Yamauchi-Takihara, B. Kellam, D. H. Anderson, L. Lin, and J. C. Liew. 1990. Complete sequence and organization of the human cardiac beta-myosin heavy chain gene. Nucleic Acids Res. 18:3647-3651.

13. Sambrook, J., A. Fritsch, and T. Maniatis, editors. 1989. Molecular Cloning: A Laboratory Manual. Cold Spring Harbor Laboratory, Cold Spring Harbor, NY. $1.25-1.28$

14. Perryman, M. B., Q.-T. Yu, A. Marian, A. Mares Jr., C. Czernuszewicz, J. Ifegwu, R. Hill, and R. Roberts. 1992. Expression of a missense mutation in the mRNA for $\beta$-myosin heavy chain in myocardial tissue. J. Clin. Invest. 90:271277.

15. Cotton, R. G. H., N. R. Rodriques, R. D. Campbell. 1988. Reactivity of cytosine and thymine in single-base-pair mismatches with hydroxylamine and osmium tetroxide and its application to the study of mutations. Proc. Natl. Acad. Sci. USA. 85:4397-4401.

16. Kogan, S. C., M. Doherty, and J. Gitschier. 1987. An improved method for prenatal diagnosis of genetic diseases by analysis of amplified DNA sequences: application to hemophilia A. N. Engl. J. Med. 317:985-990.

17. Cox, D. W., M. G. Bribacher, M. Siewertsen, J. C. Benger, B. F. Barker, and H.-P. Vosberg. 1989. Linkage relations of polymorphic markers on chromosome. Cytogenet. Cell Genet. 51:A2695. (Abstr.)

18. Pulak, R. A., and P. Anderson. 1988. Structures of spontaneous deletions in Caenorhabditis elegans. Mol. Cell. Biol. 8:3748-3754.

19. Hodgkin, J., A. Papp, R. Pulak, V. Ambros, and P. Anderson. 1989. A new kind of informational suppression in the nematode Caenorhabditis elegans. Genetics. 123:301-313. 